sciendo Порівняльна професійна педагогіка 9(4)/2019 Comparative Professional Pedagogy 9(4)/2019

DOI: $10.2478 /$ rpp-2019-0032

Teacher, VITA KHIMICH

Khmelnytskyi National University

Address: 11 Instytutska St., Khmelnytskyi, 29016, Ukraine

E-mail: vita.chimich@ukr.net

Doctor of Science in Pedagogy, Full Professor, OLENA HOMONIUK

Khmelnytskyi National University

Address: 11 Instytutska St., Khmelnytskyi, 29016, Ukraine

E-mail: elena_gomonyuk29@ukr.net

Associate Professor, MYKOLA RUDNICHENKO

Khmelnytskyi National University

Address: 11 Instytutska St., Khmelnytskyi, 29016, Ukraine

E-mail: e.em.rudnichenko@gmail.net

\title{
A COMPARATIVE ANALYSIS OF PROFESSIONAL TRAINING OF FUTURE PHYSICAL CULTURE TEACHERS IN LEADING EUROPEAN COUNTRIES
}

\begin{abstract}
The article deals with analysis of undergraduate courses for professional training of future physical culture teachers in Poland, Germany, France, and Ukraine. These countries set a number of requirements to higher educational establishments that have professionally oriented programmes for such specialists and are almost similar in majority of the countries. It has been revealed that the content of studies is oriented on current demands of the labor market and personal needs of future physical culture teachers. Forms of organization of undergraduate courses for future physical culture teachers (lectures, seminars, practical classes, individual and group projects, individual work) have been analyzed. Undergraduate courses in Poland have been analyzed. They are oriented on search of new educational training programs that would correspond to changes on national, regional, and global educational services markets and labor markets. It has been revealed that educational system in Poland includes state and private educational establishments. The research showed that the system of higher education in Poland is regulated by state legislative acts. It has been revealed that all higher educational establishments in Germany are divided into the following groups: universities, higher vocational schools giving specialized vocational training, higher educational schools (colleges) of arts and music. The research showed that each of federal lands has certain autonomy and can independently regulate educational policy and term of educational reforms implementation. It has been revealed that demands are made to teachers, namely to professional competence, knowledge, professional ability, preparedness, and skills needed for teachers to be able to solve certain educational problems. Studies consist of compulsory and elective modules. French system of education that has vivid national specifics has been analyzed in the article. It has been revealed that France has its own system of diplomas and academic degrees. It has been described that in France, university training of specialists in physical education and sport focuses on combination of fundamental theoretical education and
\end{abstract}


sciendo Порівняльна професійна педагогіка 9(4)/2019 Comparative Professional Pedagogy 9(4)/2019

professional practice. The author tackles present-day requirements to professional activity of teachers and professional training of future physical culture teachers in Ukraine. The structure of higher education in Ukraine has been built based on the structure of education on developed countries approved by UNESCO, UN and other international organizations.

Keywords: professional training, future teacher, бакалавp, specialists, physical culture, leading countries, European society.

\section{АНОТАЦІЯ}

У статті розглянуто навчання бакалаврів, а саме майбутніх вчителів фізичної культури, у Польщі, Німеччині, Франції та Україні. У статті приділясться увага розвитку вищої освіти зорієнтовану на реалізацію Болонської конвениії щодо професійної підготовки таких фахівиів, яка зорієнтована на посилення конкурентоспроможності європейської вищої освіти і передбачає перехід на дворівневу систему підготовку: бакалавр - магістр (дипломований спеиіаліст). Запровадження системи кредитів за типом ECTS змениуе навантаження на майбутніх вчителів фізичної культури. Протягом навчального семестру вони складають модульні контролі під час тижнів вільних від семестрових занять. Оцінки трунтуються на змісті навчання, уміннях та навичках. При навчанні за Болонською деклараиією розиирясться мобільність майбутніх вчителів фізичної культури та викладачів, які можуть бути затребувані європейським ринком праиі. На підставі проведеного аналізу вищі навчальні заклади Польщі, Німеччини, Франції та Украӥни пропонують бакалаврські програми для підготовки майбутніх вчителів фізичної культури, які мають модульну і семестрову організацію освітнього прочесу. Кожна з иих систем має свої особливості та переваги. Так, зміст навчання орієнтований на сучасні вимоги ринку праиі та особисті потреби майбутніх вчителів фізичної культури. Формами організації навчання таких фахівців можуть бути: лекції, семінари, практичні заняття, самостійна робота, індивідуальні та колективні проекти. У статті наведено аналіз поглядів дослідників на особливості навчання майбутніх вчителів фізичної культури у провідних країнах. Ми відзначили особливості організаиї̈ навчального прочесу, який зорієнтований на сучасний ринок праиі. Організація навчального прочесу зорієнтована на пошук нових освітніх програм, які відповідають змінам на національному, регіональному та глобальному ринках освітніх послуг. На підставі зробленого аналізу ми з'ясували, що майбутні вчителі фізичної культури мають відповідати вимогам сучасного ринку праиі. Вони відіграють ключову роль у реалізачії сочіальних иілей $і$ завдань фізичної культури. Сучасне європейське суспільство розглядає вчителя фізичної культури, який має знання, уміння,навички в професійній сфері та пропагує здоровий спосіб життя, заняття руховою діяльністю, залучає до занять різними видами спорту.

Ключові слова: професійна підготовка, майбутній учитель фізичної культури, бакалавр, фахівиі, фізична культура.

\section{INTRODUCTION}

Nowadays, the issue of the development of higher education in Ukraine, focused on implementation of the Bologna declaration guideline that would promote Ukraine's membership in European community, gains significance. In XXI Century, reformation of educational systems is an important task for each country in order to disseminate international education, active and distinct movement to mobilization of education. Analysis of international experience has gained specific significance in recent years due to 
sciendo Порівняльна професійна педагогіка 9(4)/2019 Comparative Professional Pedagogy 9(4)/2019

lack of a distinct national strategy of education internationalization. In its turn, it leads to low volume of educational services export. To improve professional training of future teachers of physical culture in Ukraine, it is important to study European experience in higher education.

THE AIM OF THE STUDY

The aim of research is to compare and analyze undergraduate courses (future teachers of physical culture) in leading countries of Europe.

\section{THEORETICAL FRAMEWORK AND RESEARCH METHODS}

Development of education in leading countries is aimed at expansion of experience and improvement of competitiveness. Nowadays, we need modernization of professional training of future specialists. Researchers analyze educational processes in Poland (N. Makarenko, M. Pidhurskyi, M. Palchuk, A. Koshchura et al.), in Germany (O. Hayduk, T. Krystopchuk, Ye. Pavlyuk, O. Sysoyeva et al.), in France (M. Gagarin, I. Hrynchenko, V. Pavlyuk, Yu. Voynar et al.), and in Ukraine (V. Vakulenko, S. Vitvytska et al.). Defining specific features of organization of educational process in such countries as Poland, Germany, France, and Ukraine became the reason for comparative analysis.

Training of future specialists in physical culture has been the focus of works by many native researchers, namely: I. Hrynchenko, A. Konyukh, Ye. Pavlyuk, B. Shyian, L. Sushchenko et al. Higher educational system in European countries has been studied by I. Babyn, Ya. Bolyubash, V. Hrubinko, V. Shynkaruk, M. Stepko, Ye. Zakharina; in universities of Canada and the USA - T. Bryha, T. Dereka, L. Kozak, V. Pavlyuk, S. Sysoyeva. Our research focuses on peculiarities of professional training of physical culture teachers at first level of higher education in leading countries of the world.

To reach the aim of research we applied general scientific methods, namely comparison and generalization, analysis and synthesis of educational processes in Poland, Germany, France, and Ukraine, revealing of differences and similarities for improvement of efficiency of native education for future specialists.

\section{RESULTS}

Development of higher education in Ukraine is oriented on implementation of the Bologna declaration, which will promote Ukraine's membership in European community. This process is aimed at expansion of experience to European education, hence, at increase of graduates' competitiveness. Social and personal value of physical culture increases as a natural means of prevention from negative influence of industrial society on person's physical and mental state. Now, society with new thinking is being formed. Thus, we have to implement contemporary European standards of education without discarding our rich heritage.

The sphere of higher education combines research activity, education, and innovations; it is a key to competitiveness of European educational system in world plain. The Bologna process envisages making systems of education similar preserving national heritage and traditions. It also offers free mobility during academic year (internship and international exchange for both students and teachers, participation in international projects) as well as opportunity to be employed in another country (participant of the Bologna process) with no need to verify diploma or complete additional courses.

According to the Bologna process, several tasks that we will analyze in detail have been planned.

Thus, one of the tasks was to implement a two-level educational process. Entrants pass entrance examinations to apply for undergraduate course; they study for four years and 
receive a diploma of bachelor, i.e. a degree of higher education. On the basis of comprehensive secondary education, students attain "degree in higher education, fundamental and special skills and knowledge regarding generalized object of activity sufficient to complete tasks and duties of certain level of professional activity envisaged for certain positions in a certain form of economic activity" (Kremin, 2004).

System of education as well as nation's culture is a unique phenomenon. It is deeply interrelated with spiritual and material aspects of the past and present. Therefore, education and its organization have specific features in each country. Movement of world community to future envisages changes in production, culture, behavior, which calls for new requirements to education. Thus, higher education also requires changes. On one hand, priority of preservation of cultural diversity of national educational systems is taking into account; on the other hand, objectives of international cooperation, mobility, employment of students are taken into account.

European countries make a number of demands to organization of studies in higher educational establishments that are practically similar in most of the countries, i.e. to put forth professionally-oriented programs in order to meet the demands and labor market; to guarantee a number of graduates without significant increase of state funding; to put forth programs, in which applied research are partially used; to update and improve existing professionally-oriented education.

In their works, S. Sysoyeva \& L. Kozak (2017) point out general features that characterize undergraduate programs of leading countries of the world, which have two methods of educational process organization, namely: modular and semester.

Modular system envisages six weeks of intensive training. During this period, students attend classes in the given subject, do group and individual tasks, and take an exam in the given subject. Upon completion of six-week period, a shift to next subject is made. Students focus on learning only one subject (Higher education abroad, e-source).

In pedagogy, a module (modulus - measure) is a functional unit of educational process. Modular education is a package of scientifically adapted programs for intensive studies, which guarantees educational achievements of students having different level of prior training. Educational module is a system of knowledge in the form of totality of knowledge and values norms systems. It is a phased discovering of this system within research and cognitive activity by a student under influence of a teacher (Modular system of education: notions, essence. Report. E-source).

Semester-type system of studies envisages a specific list of subjects (from to 6) to be learned by students throughout the semester that lasts for four months. Classes in the given subjects are held once in a week (throughout the entire day) or several times a week. Semester-type studies give opportunity to draw inter-subject connection as students have much time to learn the subject.

Professional training of future specialists in physical culture includes faculties of physical education in classic universities, colleges of physical education, pedagogical colleges and universities, sports academia, faculties of physical education in pedagogical colleges, courses for instructors of mass physical culture in classic universities (Hrynchenko, 2012).

Social value of physical culture was reflected in various documents of European Commission. Curricula of higher educational establishments of Europe include the following cycles of subjects: natural science, social and humanities, special and sports. The unified "European model" of higher educational establishments' curricula for physical 
sciendo Порівняльна професійна педагогіка 9(4)/2019 Comparative Professional Pedagogy 9(4)/2019

culture in the cycle of natural science includes physiology, anatomy, human health, biomechanics, biology, histology, physics, and chemistry. Social and humanities cycle of studies includes sociology, philosophy, foreign languages, studies of law; the cycle of pedagogical subjects includes didactics, pedagogy, psychology, theory and methods of physical education. Organization and theory of sports activities as well as sports management are part of cycle of special subjects. The cycle of sports subjects includes swimming, track-andfield, gymnastics, sport games, dancing, recreation, skiing, elective sport subject etc.

Normative documents prove that distribution of the number of academic hours between subjects in curricula of higher educational establishments of various European countries varies significantly. Their peculiar feature is variability, though they always include three types of subjects: compulsory, partially elective (by choice), totally electiveю

A distinctive feature of foreign undergraduate courses is lack of a big number of general subjects. During freshman year, students study only few general subjects related to their major. At the same time, special subjects are introduced during freshman year. Curriculum of each next year includes more and more professional subjects, which gives students a chance to attain more profound professional knowledge. When elaborating curricula, primary aim of universities is to fully introduce a student to the subject of choice. That is why undergraduate-level curricula include a significant amount of profession-related tours, practical classes, contest projects and apprenticeships (Sysoyeva, \& Kozak, 2017).

Let us analyze professional training of educators in Poland, Germany, France, and Ukraine. Undergraduate courses in Poland are oriented on search of new educational training programs that would comply with changes on national, regional, and global labor markets of educational services. System of higher education of Poland includes state and private higher educational establishments. As N. Makarenko, M. Pidhurskyi and other noted, a three-level system has been implemented in higher educational establishments of Poland. It includes bachelor's degree (licentiate, engineer) (I degree), master's degree (II degree), and Doctor of Science (III degree). To enter undergraduate course (bachelor's degree), one needs obtain secondary education certificate "maturu", which is an analog of Ukrainian external independent assessment. (Makarenko, Pidhurskyi, 2016). Polish system of higher education functions according to the norms of European Credit Transfer and Accumulation System, and according to International Standard Classification of Education. By definition of European Education Center, dimplomas issued by Polish higher educational establishments are acknowledged in all European countries and do not require special nostrification (approval) (Palchuk, 2011). Implementation of Polish educational system allowed setting it to a leading role in Europe. In academia of physical education in Poland, as has been revealed, the faculty of physical education offers the specialty of physical education with various specialties for the undergraduate course (Academy of Physical Education in Katowice. College of physical education. E-source).

As A. Koshura (2016) has noted, the system of higher education in Poland is regulated by legislation. The system of physical education in higher educational establishments of Poland tackles issues of health recreation, active rest, physical development, aesthetic attractiveness. Students elaborate "studies map", in which subjects are show regarding future profession, topic, number of academic hours, form off classes, reporting forms. A student sets the aim of physical culture and ways of its implementation in social life of the Poles, reveals tasks for state and local authorities in physical culture development (Koshura, 2016). 
sciendo Порівняльна професійна педагогіка 9(4)/2019 Comparative Professional Pedagogy 9(4)/2019

Ch. Banakh (2009) proves that Poland has made a shift from elite higher education to mass-oriented higher education. Qualitative and quantitative development of higher education is one of priority tasks of the state and society. Factors of educational and social changes in Poland till 2020 are to be: orientation on general culture and realization of European civilization values; development of qualification for employment and ability for economic efficiency; "life-long education" strategy. The linguist notes that reformation of higher education must be accompanied with a complex realization of three educational complexes: pedagogical research and experiments, practical teaching activity, and system of school management. The main priority of state's strategy has to become formation of economy based on knowledge and granting Poland a decent and effective spot in Europe (Banakh, 2009).

In his research, A. Koshura (2016) notes that higher educational establishments of Poland, based on their development, gain autonomy in defining the content of programs in students' physical education. The Ministry defines only general principles that programs must correspond to (by National Qualification Frames), while Polish Accreditation Commission can define names of programs in case of correspondence to their content.

Professional training of future physical culture teachers in Germany is focused on training highly qualified staff; a university is a center of knowledge development and propaganda. Higher education in German is characterized by interrelation of federal government and federal lands (a conference ministers of education of each land is summoned; there also exists a Union of Rectors of Higher Educational Establishments). A committee for academic planning has been established. All higher educational establishments are divided into the following groups: universities (classic, technical, comprehensive and specialized institutions of university level - higher pedagogical and medical colleges); higher vocational schools with specialized vocational training; higher education institutions (colleges) of arts and music (Innovations in education and science of certain countries of Europe, Asia, and America). First qualification of professional training for future physical culture teachers in Germany is bachelor's degree. Standard period of studies "Regelstudienzeit" at undergraduate course is 6 semesters or 3 full academic years. In applied science universities, undergraduate courses last for 6-7 semesters including practical work. In German colleges of arts and music such classes last around 8 semester or 4 academic years. In vocational academies, they last 3 academic years. In Fachschulen, undergraduate courses for future physical culture teachers last for only 2 academic years. The second qualification of professional training for future physical culture teachers in Germany is master's degree. It takes 2-4 semesters to complete master's program in Germany. In universities and educational establishments alike, as well as in colleges of arts and music, this period is mostly 4 semesters. In order to obtain the degree of a master, future physical culture teachers must obtain 300 ECTS credit scores, including scores from the previous qualification. In order to obtain a master's degree, those students whose prior degree is bachelor, must obtain 360 ECTS scores (German education System, 2019).

O. Hayduk (2012) has studied professional training of specialists in physical culture and sport in Germany and revealed that each land has certain autonomy and can independently regulate educational policy and term of educational reforms implementation.

The country's different educational establishments have individual rules regarding: a) terms of professional training of teachers (theoretical and practical phases); b) requirements to content of education (reasonable number of academic hours for each subject); c) forms, content of state examinations; d) qualification given to teachers. The 
sciendo Порівняльна професійна педагогіка 9(4)/2019 Comparative Professional Pedagogy 9(4)/2019

new system is being implemented and exists in Germany along with the traditional twolevel system of education (Hayduk, 2013).

Apart from traditional system of training of future physical culture teachers, a twolevel "bachelor - master" is being gradually implemented in Germany. At the first stage (bachelor's degree) students study for six semesters. Next stage - master's degree is optional (studies last from 2 to four semesters depending on the chosen position of a teacher).

In Germany, requirements are made to physical culture teachers regarding their professional competence, namely knowledge, professional skills, preparedness, and skills needed for tackling specific problems of education. Considering this, educational process in universities is divided into fundamental and basic stages. Fundamental stage is designed for two years and gives general theoretical training. Basic stage of educational process envisages division of studies into two aspects: practical (2 semesters) and theoretical (4 semesters). During the period of studies at basic stage, students must determine the field of their academic interests, broaden their academic knowledge, and improve practical skills gained at fundamental stage (Pavlyuk, 2013).

Studies include compulsory and elective modules. All students must pass compulsory modules and pass examinations in these modules. Students can choose an elective module within their major in a respective field of examinations. It can be changed to other during respective middle period of studies. Modules are completed with sports and practical, written, or verbal module test (exam). Requirements to the examination are set by the examination board and are announced to students via Module catalogue. Fist state examination is done upon completion of compulsory and elective modules.

Compulsory modules include studies about sport, teaching, educational competence in sport games, educational competence in winter kinds of sports, educational competence in gymnastics at apparatuses, educational competence in gymnastics and dancing, competence in health improvement, educational competence in swimming, educational competence in field-and-track, studies of training process and motions. Elective modules include practical studies related to education, studies of training process and motions, examination colloquium (Examenscolloquium), teaching how to teach (Empfohlener Studienverlauf für das Lehramtsstudium im Fach Sport an Grundund Hauptschulen als Unterrichtsfach LPO).

Second stage of training of physical culture teachers is internship or pedagogical practice (referendariat) that lasts for 24 months and completes with taking a state examination.

Analysis of professional training of physical culture teachers in Germany gives grounds for the following conclusions: there exists no general state system of professional training of physical culture teachers in the country; each land has its own structure of educational establishments. There is a traditional system of physical culture teachers training and a new one, multi-level that includes undergraduate, graduate, and postgraduate training in physical education and sports.

S. Sysoyeva and T. Krystopchuk have studied educational systems of the European Union countries and revealed that French education has been in the process of formation throughout last two centuries and is considered to be one of the best in the world. French educational system has clearly marked national specifics. France has its own system of diplomas and academic degrees, a specific division into cycles, and a special treatment of diplomas issued by state educational establishments (they, as a rule, are more highly valued than diplomas of private schools and colleges) (Sysoyeva, \& Kozak, 2012).

In France, the majority of higher educational establishments are state-run. In state universities education is free, while in private one - paid (studies are done in English). The system of professional training for future physical culture teachers in France consists of two 
cycles: "short" and "long". The "short" cycle is characterized by 2-3-year study in hgher technical lyceum, technological institutes, and specialized higher educational establishments with medical orientation. The "long" cycle is possible only in universities. The entire period of professional training for future physical culture teachers is divided into three basic stages: first stage lasts for 2 years, upon completion of which students take exams. As a result, one can receive a diploma of two types about comprehensive or scientific and technical education. The second stage lasts for 2-3 years. Upon completion of the first year of studies, graduates receive licence - a diploma of a licentiate; after second year they receive maitrise - master's diploma, after third year they receive master diploma. The third cycle is characterized with a profound study of the chosen specialty. After its completion, students receive a diploma about special DESS education, or about profound DEA (Vyshcha osvita u Frantsii, 2019).

Researchers note that a peculiar feature of higher educational system of France (higher education is acquired after secondary school and is based on "bachelor's degree") is diversity of higher educational establishments. It is impossible to analyze activity of all higher educational establishments; however, they are generally divided into two types: universities and Grand schools. Grand schools (Grandesécoles, GE), including Higher regular school, are elite commercial higher educational establishments with limited admission (Sysoyeva, \& Kozak, 2012).

Professional training of future specialists in physical culture and sports in France is done I state and private educational establishments by the fields defined by the Ministry of Education (schools, higher educational establishments), and by the Ministry of Youth Affairs, Sports and Health (mass sport, sports excellence). A lot of forms of physical culture and health improvement activities that are not part of traditional programs have appeared. Professional training of specialists is done at senior courses of physical education and sport in universities. In Claude Bernard University of Lyon, training of specialists is done by the following majors: teacher of physical culture, specialists in working with the handicapped; coach in the chosen kind of sport, sports manager (Voinar, 2005).

I. Hrynchenko has revealed that in France, university training of specialists in physical education and sport is focused on unification of fundamental theoretical and professional practice specialized in various stages of education, done under conditions of special humanities priority over natural science; a multi-level training of specialists in physical education and sport of various profiles stipulates necessity of fundamental and specialized stages, at which organization and content of education differs cardinally; fundamental training is focused on the entire complex of subjects related to future professional activity including organization and management as well as economic subjects; specialized training does not deal with subsidiary and other subjects (Hrynchenko, 2012).

M. Gagarin notes that training process in higher educational establishments of France is organized in three stages-cycles. First one is "lisas" that the French try to compare the British "bachelor"; diploma of "metriz" (similar to master) - after four years of studies; later diploma of profound training and specialized training that assure appropriate preparation to writing a PhD thesis (similar to Ukrainian "candidate of science") (Gagarin, 2017).

In 1991 Ukraine gained independence and started formation of its own policy and higher education. In 1997 under auspices of UNESCO, Lisbon Convention on defining higher education in Europe has been developed. On June 19, 1999, ministers of education of 29 European countries signed the Bologna Declaration, primary aim of which was to establish general European space of higher education (c). 
sciendo Порівняльна професійна педагогіка 9(4)/2019 Comparative Professional Pedagogy 9(4)/2019

Present-day requirements to professional activity of future physical culture teachers and their training in Ukraine are formed under influence of dominating culture traditions, social and cultural setting, social and economic as well as political transformation. Ukraine is now trying to improve the system of professional training for future physical culture teachers based on the education content updating, modernization of educational technologies taking into account achievements of the developed countries of the world.

The Ministry of Education and Science of Ukraine adopted levels and degrees of higher education (article 5, On Higher Education in last valid edition of January 16, 2016) (e-source). Training of specialists with a higher-education degree is done by appropriate educational and vocational, educational and academic, academic programs.

A system of academic degrees of professional training for future physical culture teachers in Ukraine is approximated to the structure of academic degrees of most European countries. Higher educational establishments strive to search for optimal structure and content, primarily undergraduate course, and improvement of other educational, qualification, and academic levels of such specialists' training. Reformation of higher educational system in Ukraine is needed to achieve competitiveness on labor market. Future teachers must carry out professional activates on democratic and humanitarian basis and carry out personal self-realization and self-improvement.

The educational process in higher educational establishments of Ukraine is in the following forms: classes, individual tasks, self-preparatory tasks, practical training, and tests. Basic types of classes in higher educational establishments are as follows: lectures, laboratories, practical classes, seminars, individual classes, consultations.

\section{CONCLUSIONS}

Summarizing everything mentioned above, it should be noted that undergraduate courses for future teachers of physical education in leading countries of Europe have their own peculiarities, namely: educational process is oriented on search of new educational programs that would correspond to changes on national, regional, and global educational services labor markets; educational process can be carried out by the modular and semester system; curricula are flexible - they consist of compulsory and elective modules; starting from freshman year, students study professional subjects; curricula include a significant amount of individual work and practical classes; basic forms of classes are as follows: lectures, practical classes, various types of seminars, self-preparatory work, practical work in educational establishments. Educational process is tightly connected with practical work experience in a higher educational establishment, while the role of a teacher comes to assisting a student.

Thus, future teachers of physical education must comply with requirements of present-day labor market. They play a key role in realization of social aims and tasks of physical culture. Modern European society views teachers of physical culture as specialists that has knowledge, skills in professional area, and promotes healthy lifestyle, motor activities, engages students in various kinds of sports.

Future research should define the criteria for comparing professional training of future physical culture teachers in the USA and Ukraine.

\section{REFERENCES}

1. Academy of physical education in Katowice. (2018). College of physical education. Retrieved from https:/eurostudy.info/uk/info/akademiya-fizicheskogo-vospitaniyav-katovicah. 
sciendo Порівняльна професійна педагогіка 9(4)/2019 Comparative Professional Pedagogy 9(4)/2019

2. Banach, C. (2009). Strategia rozwoju szkolnictwa wyższego w Polsce. Retrieved from http://www.kulturaswiecka.pl/node/270. 221.ukr. html.

3. Bolonskyi protses. (2018). Vziato z http://library.znu.edu.ua/articles/Statti/bolon/

4. Dubaseniuk, O. A., Antonova, O. Ie., Vitvytska, S. S., Sydorchuk, N. H., Spirin, O. M., \& Yaksa, N. V. (2008). Modeli stupenevoi pedahohichnoi osvity zakhidnoievropeiskykh krain, SShA ta Ukrainy: porivnialnyi analiz. Zhytomyr: ZhDU imrni I. Franka.

5. Empfohlener Studienverlauf für das Lehramtsstudium im Fach Sport an Grund und Hauptschulen als Unterrichtsfach LPO I \$57. (2018). Retrieved from http:// www.sp.tum.de/ fileadmin/tuspfsp/ www/ Studiengaenge/Unterrichtsfach_Sport/LA_GS_HS/FPSO_Sport _GS_HS_GESAMT.pdf.

$\overline{6}$. Gagarin, M. I. (2017). Zarubizhna systema vyshchoi osvity. Uman: Vizavi.

7. German Education System. (2019). Retrieved from https://www.studying-ingermany.org/german-education-system/\#what-makes-a-tertiary-education-in-germany

8. Haiduk, O. (2013) Osoblyvosti profesiinoi pidhotovky vchyteliv fizychnoho vykhovannia v Nimechchyni (na prykladi fakhovykh VNZ zemli Bavariia). Fizychne vykhovannia, sport i kultura zdorovia u suchasnomu suspilstvi, 2 (22), 10-16.

9. Hrynchenko, I. B. (2012). Protses profesiinoi pidhotovky maibutnikh uchyteliv fizychnoi kultury v krainakh Yevropy i v Ukraini. Pedahohichnyi dyskurs, 12, 103-109.

10. Koshura, A. V. (2016). Rozvytok fizychnoho vykhovannia v systemi vyshchoi osvity Polshchi kintsia KhKh - pochatku KhKhI stolittia. Kamianets-Podilskyi.

11. Makarenko, N. O., \& Pidhurskyi, M. I. (2016) Porivnialnyi analiz tendentsii rozvytku svitovoi ta polskoi vyshchoi osvity. Visnyk Donbaskoi derzhavnoi mashynobudivnoi akademii, 3 (39), 120-125.

12. Modulna systema navchannya: ponyattya, sutnist. (рік). Vziato z http:// ru.osvita.ua/ vnz/reports/ pedagog/ 14235/.

13. Palchuk, M. (2011). Model profesiinoi osvity i navchannia u Polshchi chetvertyi etap yevropeiskoi intehratsii. Porivnialna profesiina pedahohika, 2, 101-111.

14. Pavliuk, Ye. O. (2013) Analiz svitovoho ta vitchyznianoho dosvidu orhanizatsii fakhovoi pidhotovky maibutnikh treneriv-vykladachiv u vyshchomu navchalnomu zakladi. Pedahohichni nauky. Visnyk Natsionalnoi akademii Derzhavnoi prykordonnoi sluzhby Ukrainy, 5.

15. Pro vyshchu osvitu. № 1556-18. (2016).

16. Stepko, M. F., \& Bolyubash, Ya. Ya. (2004). Vyshcha osvita Ukrayin $i$ Bolonskyi protses. Kyiv: MON.

17. Sysoieva, S., \& Kozak, L. (2017). Neperervna osvita: zarubizhnyi dosvid. Neperervna profesiina osvita: teoriia i praktyka (seriia: pedahohichni nauky), 1-2 (50-51), 98-109.

18. Sysoieva, S. O., \& Krystopchuk, T. Ie. (2012). Osvitni systemy krain Yevropeiskoho Soiuzu: zahalna kharakterystyka. Rivne: Ovid.

19. Voinar, Yu. (2005). Rozvytok ta suchasni tendentsii systemy pidhotovky fakhivtsiv z fizychnoi kultury $v$ umovakh Yevrointehratsii. Cherkassy: Vidlunnya-Plus.

20. Vyshcha osvita u Frantsii. (2019). Vziato z https://kudapostupat.ua/vyshchaosvita-u-frantsii/.

21. Vyssheye obrazovaniye zarubezhom. (2018). Retrieved from http://yourinsa.com/ $\mathrm{ru} /$ programmy/bakalavriat. 